\title{
ГЛОБАЛЬНЫЕ ВЫЗОВЫ ТУРИСТСКОЙ ИНДУСТРИИ СТРАН АРАБСКОГО МИРА
}

\author{
(C) 2020 Радван Юунан \\ Высшая инженерно-экономическая школа \\ Санкт-Петербургский политехнический университет Петра Великого (СПбПУ), \\ Россия, Санкт-Петербург \\ E-mail: younan-r@hotmail.com \\ (c) 2020 Бумаза Абдеррахман \\ Высшая инженерно-экономическая школа \\ Санкт-Петербургский политехнический университет Петра Великого (СПбПУ), \\ Россия, Санкт-Петербург \\ E-mail: abdou.boumaza@mail.ru
}

В статье анализируются изменения в туристской индустрии стран арабского мира как результат усиления вовлеченности этих стран в процесс развития мирового туризма и реакции отрасли на глобальные вызовы, направленные на ее развитие. Описываются тенденции и изменения структуры туристских потоков, проблемы экономического, социального и экологического характера, которые в ближайшее время могут повлиять на туристскую отрасль в регионе и которые необходимо учитывать при планировании развития туризма. Обоснована роль цифровых технологий в развитии туристской отрасли в арабских странах. Сформулированы выводы, которые могут представлять интерес для лиц, изучающих современные аспекты жизни и экономики арабских стран, специалистов в области туризма, работников государственных органов, занятых в управлении туристской отраслью.

Ключевые слова: туризм, экономика туризма, страны арабского мира, Ближний Восток и Северная Африка, планирование туризма, туристский поток, гостиничный бизнес, цифровые технологии.

За последнее десятилетие страны арабского мира превратились в глобальный центр туризма и отдыха. Посетителей привлекают розничные предложения региона, отели, пляжи и уникальные впечатления. Рост числа туристских прибытий в страны Ближнего Востока и Северной Африки (БВСА) в течение ряда лет опережал средние мировые значения соответствующих показателей.

Как указано в [4], «согласно планам экономического и социального развития, а также программам формирования современной индустрии туризма, в большинстве арабских странах намечается существенно увеличить приток иностранных туристов». По оценкам Всемирной туристской организации число туристских прибытий в страны Ближнего Востока к 2030 г. может достичь 149 млн. человек.

В Индексе конкурентоспособности путешествий и туризма за 2019 год Всемирного экономического форума подчеркивается важность туризма для здоровья экономики БВСА и указывается, что туризм составляет большую долю ре- гионального ВВП, чем в любом другом регионе и что БВСА является единственным регионом, где расходы на иностранных туристов превышают расходы на местных туристов [16].

По итогам 2019 года Объединенные Арабские Эмираты получили высший рейтинг по туризму в регионе, за ними следует Катар. Ливан, Алжир и Йемен заняли самые низкие места в списке [16].

Многие исследователи отмечают высокую зависимость развития туризма в арабских странах от геополитической ситуации [11; 14]. В [11] указывается на наличие высокого отложенного спроса на туризм в регионе, который будет высвобождаться по мере стабилизации геополитической обстановки и укрепления доверия туристов. Вместе с тем, в [15] описан парадокс быстрого расширения туристских потоков на арабский Ближний Восток после ряда событий, в частности, серии нападений на туристов в регионе, которые по общепринятому, мнению, должны были негативно повлиять на туризм, что бросает вызов общепринятым взглядам на 
уязвимость туризма перед геополитической нестабильностью.

Исследование туристского потока методами фрактального анализа выявило наличие долговременной памяти и трендовый характер динамики международных прибытий на Ближнем Востоке. Значение показателя Хёрста, отражающего персистентность международного туристского потока в регионе, то есть эмпирическую вероятность того, что возрастание туристского потока в прошлом приводит к его возрастанию в дальнейшем, и напротив, снижение потока в прошлом приводит к его дальнейшему снижению, за 1978-2017 гг. равно 0,992. Следует заметить, что значения показателя для мирового и европейского туристских потоков несколько меньше: $\mathrm{H}=0,9535, \mathrm{H}=0,956$ соответственно [12].

Туристская индустрия арабского мира не может оставаться в стороне от мировых тенденций, к числу которых относятся [14]:

- демографические и социальные изменения;

- смена мировых экономических держав;

- ускорение урбанизации;

- изменение климата и нехватка ресурсов;

- технологические прорывы.

Цель данной статьи - выявить возможные реакции туристской индустрии стран БВСА на глобальные вызовы.

С экономической точки зрения арабский мир не является однородным пространством, что наглядно проявляется в уровне доходов населения (табл. 1). При этом средняя величина дохода от туристского прибытия гораздо более однородна. Если отношение среднего квадра- тичного отклонения среднедушевого дохода по указанным в табл. 1 странам составляет $105 \%$ от среднего значения показателя, то для среднего дохода от туристского прибытия это отношение лишь немногим больше 9\%.

Учитывая отмеченное в [4] стремление большинства арабских стран к развитию туризма и перераспределению сложившихся туристических потоков в мире в пользу стран региона в ближайшей и среднесрочной перспективе, в первую очередь необходимо сосредоточить внимание на общих подходах к поиску ответов на глобальные вызовы.

Исторически индустрия туризма создавалась для обслуживания деловых людей и путешественников среднего возраста из стран с развитой экономикой. Происходящие в мире демографические изменения: старение населения, которое наиболее выражено в странах с развитой экономикой, и изменение вкусов и потребностей, проявляющееся у лиц, принадлежащих к новым поколениям, несут с собой как проблемы, так и возможности.

Известно, что требования размещению существенно различаются от целей поездки, привычек и возраста туристов. Поскольку в сфере размещения формируется значительная доля удовлетворенности туристов, на социальнодемографические изменения в первую очередь должна реагировать гостиничная индустрии.

Большинство крупных отелей в странах арабского мира принадлежит иностранным компаниям. В регионе реализуются крупные проекты в сфере гостиничного строительства, по обустройству туристических центров, предо-

Таблица 1. Показатели среднедушевого дохода и среднего дохода от туристских прибытий, долл. США [16]

\begin{tabular}{|l|c|c|}
\hline \multicolumn{1}{|c|}{ Страна } & ВВП на душу населения & Средний доход от прибытия \\
\hline Йемен & 944 & 533,5 \\
\hline ОАЭ & 43005 & 527,5 \\
\hline Катар & 68794 & 500,5 \\
\hline Оман & 16415 & 492,5 \\
\hline Бахрейн & 24051 & 404,5 \\
\hline Египет & 2549 & 433,5 \\
\hline Марокко & 3238 & 483,5 \\
\hline Саудовская Аравия & 23339 & 504,5 \\
\hline Иордания & 4242 & 459,5 \\
\hline Тунис & 3448 & 523,5 \\
\hline Кувейт & 33994 & 463,5 \\
\hline Ливан & 7242 & 467,5 \\
\hline Алжир & 4115 & 397,5 \\
\hline
\end{tabular}


ставляющих широкий комплекс современных туристических услуг [4]. Объем предложения постоянно растет, конкуренция на рынке ужесточается, что ведет к снижению цен. Все более явно проявляется сдвиг предпочтений в пользу недорогих отелей среднерыночного сегмента. растущее число гостиниц среднерыночного сегмента и бюджетных отелей становится еще одним фактором снижения цен [10].

Адаптация отелей региона к социальнодемографическим изменениям может обеспечиваться:

1) инновациями в брендинге отелей - создании брендов, воплощающих индивидуальность различных туристических сегментов за счет соответствующего дизайна и технологий;

2) проактивной реакцией в конкурентной борьбе с онлайн-площадками - посредниками в краткосрочной аренде частного жилья, например, Airbnb. В настоящее время онлайнплощадки главным образом удовлетворяют спрос частных путешественников, тогда как деловые путешественники пока остаются преимущественно клиентами отелей, однако ситуация быстро меняется. Для сохранения посетителей делового сегмента и возврата части утраченных клиентов отели должны усиливать ориентацию на потребителя и создавать уникальный гостевой опыт за счет индивидуализации услуг и сильной идентичности;

3) смещением информационного аспекта маркетинговой стратегии в сторону присутствия в социальных сетях, сочетания интернетрекламы с пропагандой. Последнее требует обеспечения заинтересованности лиц, имеющих влияние в интернет-пространстве;

4) расширением использования цифровых технологий - от автоматизированных бронирований и электронных маршрутов до мобильных проверок и развлекательных платформ с использованием собственных устройств,- позволяющих туристам лучше контролировать свои действия и принимать более активное участие в процессе планирования путешествий.

В современном мире экономическая мощь перешла от развитых к развивающимся экономикам Азии, Африки и Латинской Америки, на которые уже приходится более половины мирового ВВП. В результате этого сдвига Ближний Восток оказался в центре многих быстрорастущих рынков. По экспертным оценкам в обозримом будущем страны с развивающейся экономикой превзойдут страны с развитой экономикой по числу международных туристских прибытий - к 2030 году наибольшее количество прибытий будет из стран Азиатско-Тихоокеанского региона (АТР). Перспективными и уже частично реализуемыми мерами, учитывающими эти изменения, со стороны туристской индустрии арабских стран могут быть:

1) установление прямого транспортного сообщения со странами - потенциальными источниками массового туристского потока (в частности, Китая и Индии);

2) упрощение визовых процедур;

3) предоставление розничного предложения мирового класса;

4) проведение разнообразных мероприятий с учетом потенциальных интересов меняющегося контингента туристов;

5) использование поддержки влиятельных лиц в Интернете и традиционных маркетинговых инструментов для продвижения ближневосточных дестинаций в странах АТР.

В настоящее время около 50\% населения мира проживает в городах, и ООН прогнозирует, что к 2030 году городскими жителями будут 4,9 миллиарда человек. В странах Персидского залива уже сейчас в городах проживает $85 \%$ населения и ожидается, что к 2050 году эта цифра вырастет до 90\%.

Урбанизация способствует созданию благоприятной среды для туризма, так как улучшает транспортное сообщение и информационные возможности, открывая перспективу для создания «умных дестинаций» [5]. Однако неконтролируемая быстрая урбанизация создает серьезные проблемы для национальных и местных органов власти, связанные с ограниченными возможностями инфраструктуры, недостаточностью текущего финансирования и инвестиций в предоставление услуг, ненадлежащее планирование и нехватка ресурсов.

В связи с этим повышается актуальность оптимизации государственно-административных мер регулирования туристского потока, в том числе, налогообложения туристской индустрии [1] - туристов и/или организаций туристского бизнеса, и использование принципов геоэкомаркетинга при планировании пропускной способности дестинаций, отбельных туристских объектов и управлении туристским потоком [2].

Обратная сторона городского туризма - это отрицательное воздействие на окружающую 
Таблица 2. Сроки исчерпания годового объема воспроизводимых ресурсов в арабских странах [13]

\begin{tabular}{|l|c|l|c|}
\hline \multicolumn{1}{|c|}{ Страна } & \multicolumn{1}{|c|}{$\begin{array}{c}\text { Дата исчерпания } \\
\text { ресурсов }\end{array}$} & \multicolumn{1}{c|}{$\begin{array}{c}\text { Дата исчерпания } \\
\text { ресурсов }\end{array}$} \\
\hline Катар & 11.02 .2020 & Саудовская Аравия & 05.04 .2020 \\
\hline ОАЭ & 07.03 .2020 & Алжир & 04.09 .2020 \\
\hline Бахрейн & 10.03 .2020 & Иордания & 13.10 .2020 \\
\hline Кувейт & 10.03 .2020 & Египет & 25.11 .2020 \\
\hline Оман & 29.03 .2020 & Марокко & 18.12 .2020 \\
\hline
\end{tabular}

среду, включая загрязнение воздуха, шумовое загрязнение и чрезмерное использование ресурсов. Данные табл. 2, где приводятся данные о сроках, к которым отдельные страны арабского мира в 2020 году использовали объем природных ресурсов, воспроизводимый на их территории за год [13], подтверждают остроту проблемы ресурсосбережения.

Страны Ближнего Востока имеют одни из самых высоких уровней в мире по потреблению энергии и воды на душу населения. Учитывая, что эти страны уже сталкиваются с дефицитом природной пресной воды, а наращивание мощности опреснительных установок значительно увеличивает общее энергопотребление, туристский поток должен быть согласован с имеющимися технико-технологическими возможностями. В [3] описаны некоторые возможности обеспечения энергосбережения и повышения энергоэффективности туристской отрасли, которые следует учитывать при разработке политики в отношении туризма, поощряющей рациональное использование ресурсов, включающие в себя обязательный энергоаудит.

Ближний Восток обладает крупнейшими запасами углеводородного сырья, однако сжи- гание нефти и газа для производства электроэнергии и опресненной воды создает мощный углеродный след и наряду с прочими факторами способствует изменению климата в регионе и росту среднегодовой температуры. Влияние изменения климата на туристский поток оценивается как отрицательное, поскольку более жаркая погода снизит количество посетителей.

Bсе участники производственно-сбытовой цепочки туризма - государственные органы, метеорологические службы, туроператоры, гостиничные операторы и туристы - должны заботиться о смягчении последствий изменения климата.

Цифровые технологии проникают в индустрии туризма по всей цепочке создания стоимости. Процесс от принятия решения о поездке до получения обратной связи после завершения поездки может быть полностью выполнен на цифровой платформе. Проникновение смартфонов на рынки стран Персидского залива является одним из самых высоких в мире, достигая 78\% в ОАЭ и 77\% в Саудовской Аравии, что дает возможность этим странам задавать ориентир для других в части использования цифровых технологий в туризме.

\section{Библиографический список}

1. Гузикова Л.А., Колесников А. М. Налогообложение как фактор инвестиционной привлекательности и конкурентоспособности туристического бизнеса //Известия Тульского государственного университета. Экономические и юридические науки. 2017. № 1-1. С. 265-274.

2. Гузикова Л.А., Колесников А.М. Экономические аспекты геоэкомаркетинга в сфере туризма //Вестник Северо-Кавказского федерального университета. 2017. № 2 (59). С. 44-50.

3. Гузикова Л.А., Колесников А. М., Шехматова К. О. Туристская отрасль как сфера энергопотребления // Вестник Северо-Кавказского федерального университета. 2019. № 1 (70). С. 39-46.

4. Кхалаф, М. М. Развитие индустрии туризма в странах Ближнего Востока и Северной Африки: Вторая половина XX-начало XXI в. Автореферат диссертации на соискание ученой степени кандидата экономических наук по специальности 08.00.14 «Мировая экономика», М.: 2004.

5. Радван Ю., Гузикова Л. А. От цифрового туризма к умному туризму / В сборнике: Цифровая экономика и индустрия 4.0: Форсайт Россия. сборник трудов научно-практической конференции с зарубежным участием. Санкт-Петербургский политехнический университет Петра Великого. 2020. С. 244-249. 
6. Родионов Д.Г. К формированию в городах России зон туристско-рекреационной и сервисной специализации // Проблемы современной экономики. 2004. № 1-2 (9-10). С. 150-151.

7. Родионов Д.Г., Баранова И. В., Насрутдинов М.Н. Идентификация ключевых медиаторов развития социального потенциала региона // Российский экономический интернет-журнал. 2019. № 3. С. 69.

8. Родионов Д.Г., Баранова И. В., Насрутдинов М. Н. Формирование модели интерферирования показателей социального потенциала региона // Российский экономический интернет-журнал. 2019. №4. С. 119.

9. Родионов Д.Г., Дегтерева В.А., Баранова И.В. Преодоление бедности как основное условие повышения уровня жизни населения региона // Известия Иркутской государственной экономической академии. 2008. № 3. C. 132-137.

10. Стеканова, B., 2013. Неоднородный рынок Ближнего Востока: отели на любой вкус и бюджет [Электронный ресурс] - Режим доступа http://businesstravelrussia.ru/news/news-abt/neodnorodnyy-rynok-blizhnegovostoka-oteli-na-lyuboy-vkus-i-byudzhet/ (дата обращения 03.09.2020).

11. Шмыткова А.В., Чечётенко Ю.С. Влияние геополитической обстановки на развитие туризма на ближнем востоке в XXI веке //Крымский научный вестник. 2017. № 2-3 (14-15). С. 57-65.

12. Щелкунова Л.И., Емец М. С. Фрактальный анализ динамики международных прибытий в туризме //Бизнес информ. 2019. № 1 (492). С. 178-183.

13. Earth Overshoot Day [Электронный ресурс] - Режим доступа https://www.overshootday.org/newsroom/ country-overshoot-days/ (дата обращения 03.09.2020).

14. Global megatrends ....and their impact on the Middle East's travel and tourism industry [Электронный ресурс] - Режим доступа https://www.pwc.com/m1/en/publications/global-megatrends-impact-middle-easttravel-tourism-industry.html (дата обращения 02.09.2020).

15. Hazbun, Waleed, 2006. Explaining the Arab Middle East Tourism Paradox. The Arab World Geographer/Le Géographe du monde arabe. 9(3), 201-214.

16. Uppink, L, Soshkin, M. The Travel \& Tourism Competitiveness Report 2019 Travel and Tourism at a Tipping Point [Электронный ресурс] - Режим доступа https://www.weforum.org/reports/the-travel-tourism-competitivenessreport-2019 (дата обращения 02.09.2020). 